\title{
ANALISIS TEKAN KOMPOSIT LAMINASI KAYU - BAJA RINGAN BERDASARKAN SNI 7973-2013
}

\author{
Kundari Rahmawati ${ }^{1}$,Fajar Danur Isnantyo ${ }^{1}$ \\ Email: kundari.rahmawati@staff.uns.ac.id
}

\begin{abstract}
Abstrak
Kayu mahoni (Swietenia Mahagoni) merupakan kayu kelas kuat III dengan berat jenis 0,56 sampai dengan 0,72 dan ketahanan kayu mahoni terhadap rayap kayu kering (Cryptotermes Cynocephalus Light) termasuk dalam kelas awet kelas III. Sedangkan profil baja ringan adalah jenis profil baja yang memiliki rasio berat dan kekuatan yang tinggi, Oleh karena itu penulis memilih baja ringan sebagai material yang akan dikompositkan dengan kayu sebagai material penahan beban tekan. Pengujian perilaku tekan komposit laminasi kayu-baja ringan dilakukan pemodelan eksperimental benda uji batang komposit dengan skala geometri model pada benda uji adalah skala penuh (full scale), dengan jarak antar antar sekrup $200 \mathrm{~mm}$ pada setiap sisi badan baja ringannya. Untuk mengetahui perilaku tekan batang komposit tersebut dilakukan pemodelan dengan batang komposit dengan panjang tekuk $\left(\mathrm{L}_{\mathrm{k}}\right) 200 \mathrm{~mm}, 300 \mathrm{~mm}$, $600 \mathrm{~mm}, 900 \mathrm{~mm}$ dan $1200 \mathrm{~mm}$. Deformasi lateral batang komposit diukur dengan memasangkan LVDT dari arah lateral pada saat pelaksanaan pembebanan. Pola kegagalan batang komposit laminasi kayu-baja ringan juga diamati dalam pengujian ini. Pada setiap panjang tekuk dilakukan tiga kali pengulangan pembebaban. Hasil penelitian ini menunjukan bahwa laminasi kayu mahoni memiliki kapasitas tekan kayu mahoni 5 kali lipat lebih besar jika dibandingkan dengan analisis teori transfomasi tampang yang mengacu pada SNI 79732013 Spesifikasi desain untuk konstruksi kayu. Model keruntuhan batang komposit adalah tekuk pada sayap profil baja ringannya, dan pada badan secara keseluruan model kegagalannya hanya mengalami tekuk global akibat kelangsingan batangnya bukan hancur karena penampang.
\end{abstract}

Kata kunci: tekan, komposit, baja ringan, Swietenia mahagoni.

\begin{abstract}
Mahogany (Swietenia Mahagoni) is wood strength classification III with specific gravity of 0.56 to 0.72 and the resistance of mahogany to dry wood termites (Cryptotermes Cynocephalus Light) is wood durability classification III. Meanwhile, cold formed steel is a type of steel profile that has a high ratio of weight and strength, therefore the researcher opted cold formed steel as a material to be composited with wood as a compressive load retaining material. Testing on compressive behavior of laminate composite of cold formed steel was carried out by experimental modeling on composite beam specimens with model geometry scale on the test object is full scale, with the distance between the screws $200 \mathrm{~mm}$ on each side of cold formed steel web. Modeling with composite beams with buckling length (Lk) $200 \mathrm{~mm}, 300 \mathrm{~mm}, 600 \mathrm{~mm}, 900 \mathrm{~mm}$ and $1200 \mathrm{~mm}$ was carried out to determine the composite behavior of the composite beam. Composite beam lateral deformation was measured by three LVDTs attached on the specimens during loading. Failure mode of timber lamina - cold formed steel composite was also observed. At each buckling length, three repetitions were carried out. The results of this study indicates that laminated mahogany has compressive behavior up to 5 times compared to the analysis of transformation theory that refers to SNI 7973-2013 about Design Specifications for Wood Construction. Composite beam collapse model is buckling on the flens of cold formed steel, also global buckling on its web due to its slenderness.
\end{abstract}

Keywords: compresion, composite, cold formed steel, Swietenia mahagoni.

${ }^{1}$ Pengajar Program Studi Pendidikan Teknik Bangunan Universitas Sebelas Maret 


\section{PENDAHULUAN}

\section{Latar Belakang}

Dalam konstruksi struktural, selain memenuhi persyaratan keteguhan atau kekuatan memikul beban rencana, kayu juga harus memiliki kekakuan dan kestabilan struktur. Oleh karena itu, perlu dilakukan desain untuk mendapatkan struktur yang ideal. Sifat fisik dan mekanik kayu yang akan digunakan dalam sebuah konstruksi struktural adalah salah satu hal yang harus dipertimbangkan.

Wahyu (2008), mengemukakan faktorfaktor alam yang mempengaruhi sifat-sifat dan mekanik kayu dapat dikelompokkan menjadi jenis kayu, tempat tumbuh, umur, letak dalam batang, diameter dan lain-lain.

Kelas kuat kayu di Indonesia menggunakan berat jenis sebagai salah satu parameternya. Dalam atlas kayu yang diterbitkan oleh Pustitbang Teknologi Hasil Hutan tahun 1989 menyebutkan bahwa kayu mahoni (Swietenia Mahagoni) merupakan kayu kelas awet II-III dengan berat jenis 0,56 sampai dengan 0,72. Kayu mahoni secara umum termasuk dalam kayu dengan kelas awet III, ketahanan kayu mahoni terhadap rayap kayu kering (Cryptotermes Cynocephalus Light) termasuk kelas III.

Li (2005) melakukan penelitian eksperimental mengenai perilaku komposit profil baja ringan $\mathrm{C}$ dengan kayu dan atau Oriented strand board (OSB) dengan konektor geser sekrup menghasilkan kesimpulan bahwa komposit material ini terbukti efektif meningkatkan kekakuan lentur material tersebut. Oleh karena itu, penulis memilih baja ringan sebagai material yang akan dikompositkan dengan kayu sebagai material penahan beban tekan.

Penelitian ini dilakukan penelitian eksperimental dengan skala geometri model adalah skala penuh (full scale). Dilakukan pembebanan tekan statik searah sumbu batang komposit. Dilakukan pengujian pendahuluan material untuk mengetahui kekuatan sekrup, baja ringan dan kayu yang akan digunakan dalam material komposit laminasi kayu-baja ringan. Jarak antar sekrup sebagai konektor geser tidak ditinjau dalam penelitian ini dan kayu yang digunakan adalah kayu jenis mahoni (Swietenia Mahagoni). Perilaku kuat tekan material komposit laminasi kayu-baja ringan dengan konektor geser sekrup yang terpasang pada badan profil baja ringan sebagai parameter yang akan diteliti dalam eksperimen ini.

Penelitian ini dibuat model eksperimen batang komposit laminasi kayu-baja ringan bertujuan meningkatkan kapasitas tekan pada kayu mahoni dan mengetahui perilaku mekanik batang komposit laminasi kayu-baja ringan akibat beban tekan dan pola kegagalan batang komposit laminasi kayu-baja ringan yang terjadi akibat beban tekan.

\section{METODE PENELITIAN}

\section{Bahan Penelitian}

Material yang digunakan dalam penelitian ini adalah profil baja ringan $75 \mathrm{Z} 08$ dengan lebar web $75 \mathrm{~mm}$, lebar flens masing masing $30 \mathrm{~mm}$ dan tebal $0,8 \mathrm{~mm}$; kayu mahoni (Swietenia Mahagoni) yang tumbuh sekitar Daerah Istimewa Yogyakarta lebar $74 \mathrm{~mm}$ dan tebal $14 \mathrm{~mm}$; sekrup diameter $4 \mathrm{~mm}$ dan panjang 50 mm.

\section{Benda Uji Penelitian}

Untuk mengetahui perilaku struktur batang komposit laminasi kayu-baja ringan akibat beban aksial tekan dilakukan pemodelan eksperimental benda uji batang komposit dengan skala geometri model pada benda uji adalah skala penuh (full scale), dengan jarak antar antar sekrup $200 \mathrm{~mm}$ pada setiap sisi badannya. Pemodelan benda uji seperti terlihat pada Gambar 2 berikut:

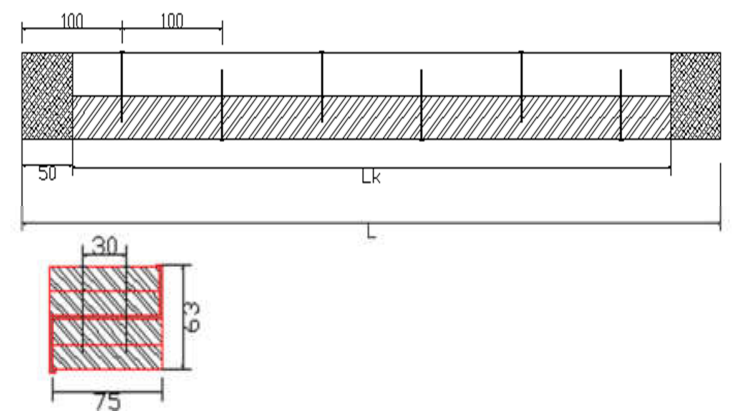

Gambar 2. Model benda uji komposit laminasi kayu-baja ringan (unit mm). 
Dilakukan tiga kali pengulangan pembebanan untuk setiap model benda uji dengan panjang tekuk $\left(\mathrm{L}_{\mathrm{k}}\right)$ tertentu.

\section{Pelaksanaan Pengujian}

\subsection{Pengujian Kuat Tekan Sejajar serat Kayu Mahoni}

Pengujian tekan aksial sejajar serat kayu mahoni, spesimen dan metode pengujian berdasarkan peraturan British Standar 373:1957.

\subsection{Pengujian Lentur Kayu Mahoni}

Dalam pengujian lentur kayu mahoni, spesimen dan metode pengujian berdasarkan peraturan British Standar 373:1957 Methods of testing small clear specimens of timber. Dari pengujian ini didapatkan nilai Modulus of Elasticity (MOE) dan Modulus of Repture (MOR).

\subsection{Pengukuran Kadar Air dan Berat Jenis}

Untuk mengetahui kadar air kayu mahoni yang digunakan sebagai bagian dari struktur komposit maka dilakukan pengukuran kadar air sesuai British Standar 373:1957.

\subsection{Pengujian Kuat Tarik Baja Ringan}

Untuk mengetahui nilai tegangan leleh ( $f y$ ) dan modulus elastisitas baja ringan yang digunakan dalam penelitian ini, maka dilakukan pengujian tarik baja tersebut dengan berpedoman pada standart ASTM E8M-034 2004 Standard Test Methods for Tension Testing of Metallic Materials [Metric] 1.

\subsection{Pengujian Kuat Tarik Sekrup}

Untuk mengetahui ketahan satu buah sekrup dalam menahan beban maka dilakukan pengujian tarik sekrup dengan mengacu pada standart ASTM E 8M-04 Standard Test Methods for Tension Testing of Metallic Materials.

\subsection{Pengujian Lentur Batang Komposit}

Dalam penelitian ini dilakukan pengujian lentur batang komposit untuk dapat mengetahui nilai modulus elastisitasnya. Setting pengujian lentur batang komposit baja ringan-kayu berdasarkan SNI 033975-1995.

\subsection{Pengujian Kuat Tekan Komposit Laminasi Kayu-Baja Ringan}

Parameter yang akan diperoleh dari penelitian ini adalah besarnya beban kritis $\left(\mathrm{P}_{\mathrm{cr}}\right)$ dan deformasi arah lateral pada benda uji akibat beban aksial. Setting pengujian terlihat seperti pada Gambar 5 .

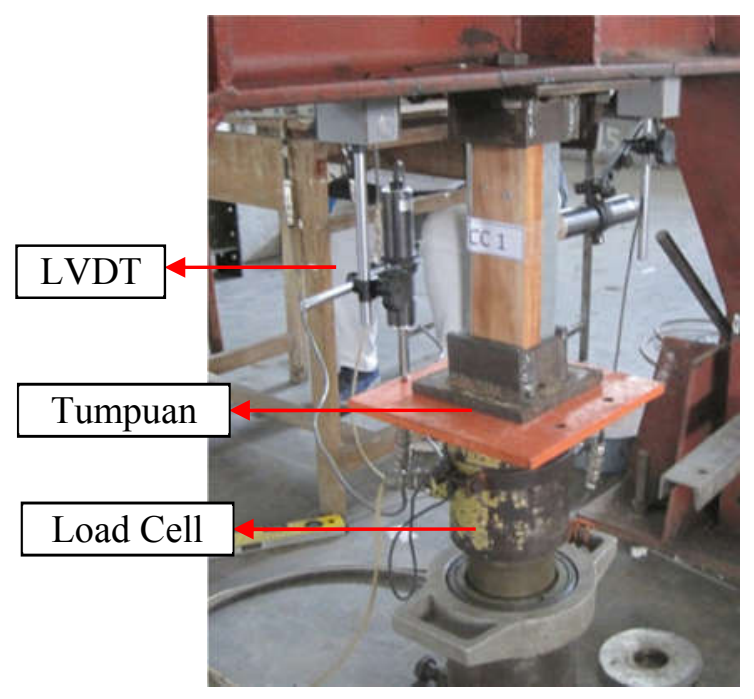

Gambar 5. Setting pengujian tekan komposit baja ringan-kayu

\section{HASIL PENELITIAN DAN PEMBAHASAN \\ 1. Pengujian Material}

Pada Tabel 1 dapat dilihat hasil pengujian karakteristik material yang digunakan dalam pengujian ini.

Tabel 1. Hasil Pengujian Material

\begin{tabular}{|c|l|c|}
\hline No & \multicolumn{1}{|c|}{ Jenis Pengujian } & Nilai \\
\hline 1. & $\begin{array}{l}\text { Kuat Tekan Kayu mahoni }(f e, \\
\text { MPa) }\end{array}$ & 43,53 \\
\hline 2. & $\begin{array}{l}\text { Kuat Lentur Kayu Mahoni } \\
\text { (MOE, MPa) }\end{array}$ & $\begin{array}{c}6130,7 \\
3\end{array}$ \\
\hline 3. & $\begin{array}{l}\text { Kuat Lentur Kayu Mahoni } \\
\text { (MOR, MPa) }\end{array}$ & 76,48 \\
\hline 4. & Kadar Air (\%) & 12,24 \\
\hline 5. & BJ Kering Udara & 0,69 \\
\hline 6. & Tarik Baja Ringan (fy, MPa) & 591 \\
\hline 7. & Tarik Sekrup (fy, MPa) & 1134 \\
\hline 8. & $\begin{array}{l}\text { Lentur Komposit (MOE, } \\
\text { MPa) }\end{array}$ & 2946 \\
\hline 9. & $\begin{array}{l}\text { Lentur Komposit (MOR, } \\
\text { Nmm) }\end{array}$ & 144585 \\
0
\end{tabular}




\section{Pengujian Tekan Komposit Laminasi Kayu-Baja Ringan}

Pengujian tekan komposit laminasi kayubaja ringan dilakukan dengan tiga kali pengulangan pada tiap-tiap bentangnya. Setting pengujian ini disusun sedemikian rupa seperti yang dijelaskan pada bab sebelumnya untuk menghindari terjadinya kecelakaan pada saat proses pembebanan. Beban maksimum yang didapatkan pada pengujian ini tersaji dalam tabel berikut ini (Tabel 2).

Tabel 2. Hasil pengujian tekan komposit laminasi kayu-baja ringan.

\begin{tabular}{||l|r|r||}
\hline Kode & $\mathrm{L}_{\mathrm{k}}(\mathrm{mm})$ & \multicolumn{1}{c|}{$\mathrm{P}_{\max }(\mathrm{kN})$} \\
\hline CSC1 & 200 & 198,83 \\
\hline CSC2 & 200 & 194,70 \\
\hline CSC3 & 200 & 228,53 \\
\hline CSC4 & 300 & 154,28 \\
\hline CSC5 & 300 & 158,40 \\
\hline CSC6 & 300 & 157,58 \\
\hline CSC7 & 600 & 115,50 \\
\hline CSC 8 & 600 & 92,40 \\
\hline CSC9 & 600 & 122,93 \\
\hline CSC10 & 900 & 92,40 \\
\hline CSC11 & 900 & 65,18 \\
\hline CSC12 & 900 & 86,63 \\
\hline CSC13 & 1200 & 49,50 \\
\hline CSC14 & 1200 & 73,43 \\
\hline CSC15 & 1200 & 51,15 \\
\hline \hline
\end{tabular}

Hasil pengujian batang komposit laminasi kayu-baja ringan dalam penelitian ini dibandingkan dengan analasis teoritis. Analisis secara teori dilakukan dengan dua cara yaitu menggunakan pendekatan persamaan Euler dan pendekatan metode transformasi tampang berdasarkan SNI 7973:2013. Gambar 12 menunjukan perbandingan hasil eksperimen dengan hasil analisis dengan menggunakan pendekatan tekuk Euler dan Transformasi Tampang.

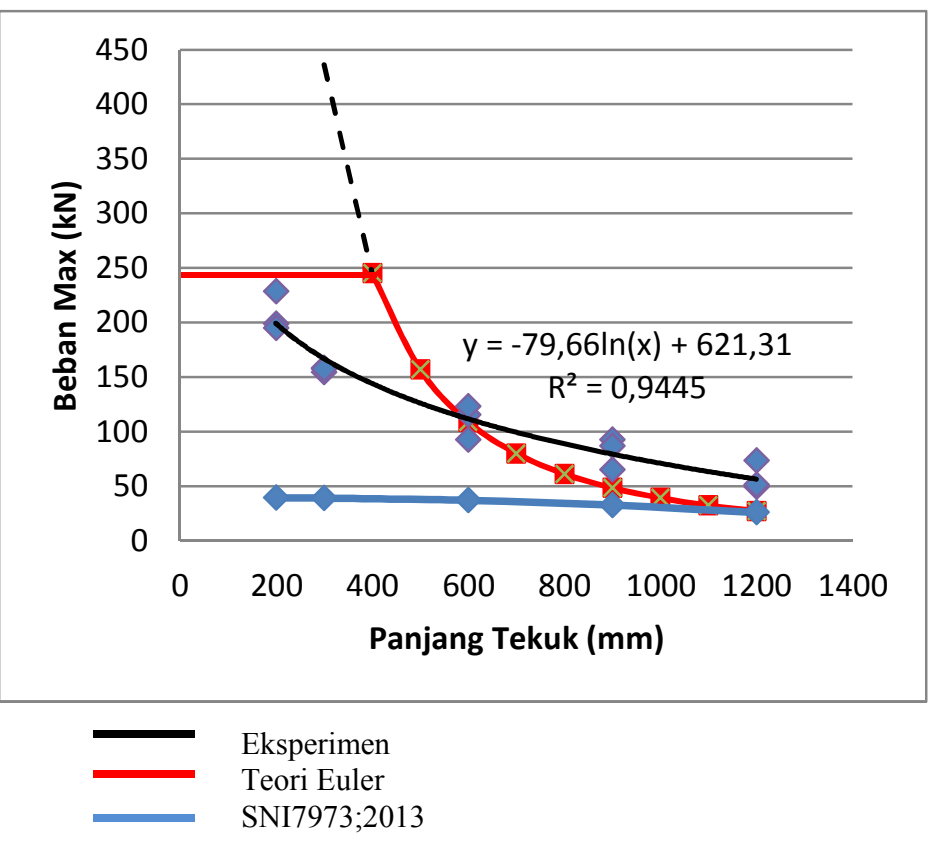

Gambar 12. Grafik hubungan beban maksimum dan panjang bentang .

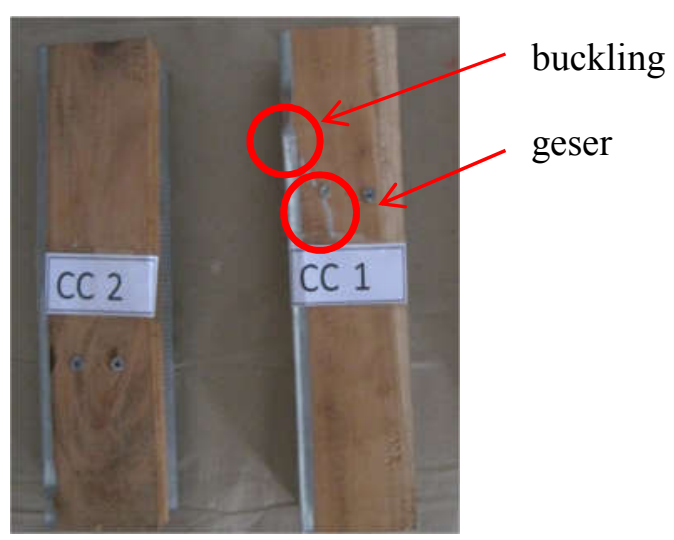

Gambar 13. Pola kegagalan komposit laminasi kayu-baja ringan bentang pendek.

Pola kegagalan yang terjadi pada struktur komposit ini bervariasi. Pada batang komposit dengan panjang tekuk $\left(\mathrm{L}_{\mathrm{k}}\right) 200$ $\mathrm{mm}$ terjadi kegagalan geser dan local buckling pada sayap profil baja ringan dan global buckling pada keseluruhan batangnya. Untuk batang yang lain tidak terjadi kegagalan geser pada penampangnya. Pola kegagalan berupa global buckling dan local buckling pada sayapnya. Batang komposit dengan panjang tekuk (Lk) $1200 \mathrm{~mm}$ cenderung hanya terjadi global buckling dan sedikit local buckling pada sayap profil baja ringan. 


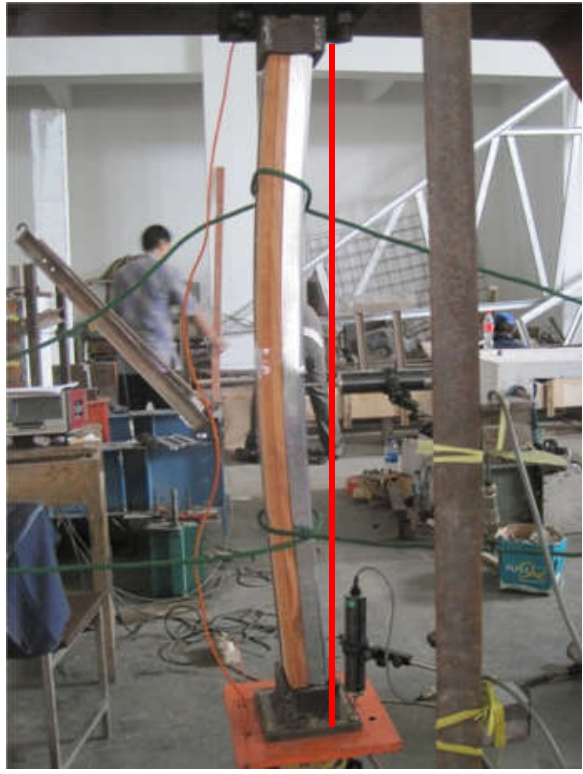

Gambar 14. Pola kegagalan global buckling batang komposit baja ringankayu

Pada batang komposit dengan panjang bentang $1200 \mathrm{~mm}$ terlihat pada Gambar 16 data masih didalam batas kegagalan struktur yang diijinkan. Dalam artian batang komposit tersebut belum mengalami kegagalan saat pengujian. Pada saat pelaksanaan pengujian batang komposit dengan panjang $1200 \mathrm{~mm}$ dihentikan ketika beban yang mampu ditahan oleh struktur tersebut menurun $20 \%$ dari beban maksimum yang telah tercapai.

Secara ideal posisi pola kegagalan seharusnya di sekitar garis batas yield, namun beberapa batang komposit terlampaui jauh dari batas garis tersebut. Hal ini berkaitan dengan materal kayu yang tidak homogen pada setiap batangnya. Nampak pada batang komposit dengan panjang tekuk $600 \mathrm{~mm}$ semuanya berada jauh dari garis yield dari struktur tersebut.

Dari keseluruhan pengujian tidak terjadi kegagalan pada material kayu, kegagalan terjadi hanya pada baja ringan.

Tujuan penelitian ini adalah meningkatkan kapasitas tekan pada kayu mahoni dan mengetahui perilaku mekanik batang komposit laminasi kayu-baja ringan akibat beban tekan dan pola kegagalan batang

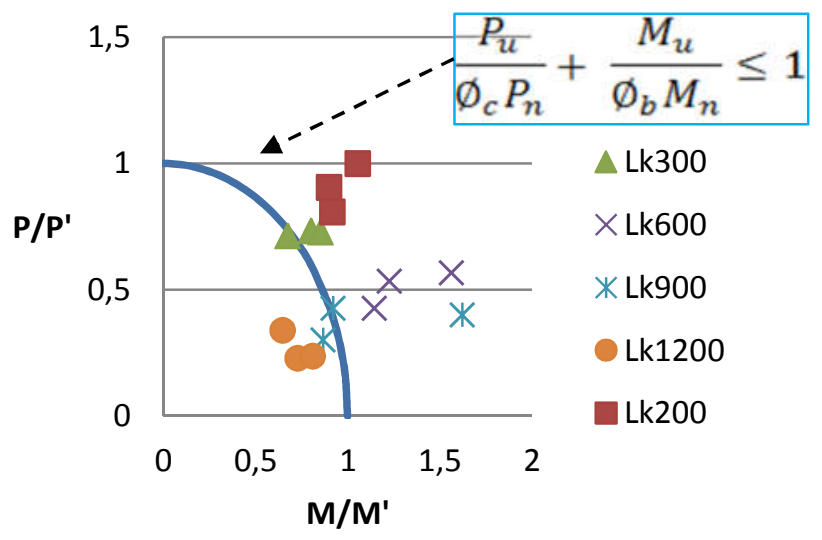

Gambar 15. Grafik Hubungan beban dan momen lentur akibat beban aksial tekan batang komposit laminasi kayu-baja ringan

komposit laminasi kayu-baja ringan yang terjadi akibat beban tekan. Uraian diatas menjelaskan sifat mekanis dari profil baja ringan dan batang komposit laminasi kayu-baja ringan. Pemasangan baja ringan sebagai material komposit secara cenderung kapasitas tekannya lebih besar dibandingkan dengan hasil analisis penampang dengan mentranformasikan tamoang komposit yang dihitung berdasarkan SNI 7379:2013.

Tabel 4. Perbandingan Kapasitas Tekan Batang Komposit Laminasi Kayu-Baja Ringan dengan Analisis Transformasi tampang (mengacu SNI 7379:2013)

\begin{tabular}{|c|r|r|r|}
\hline \hline $\begin{array}{c}\text { Lk } \\
(\mathrm{mm})\end{array}$ & Pcr Teori & $\begin{array}{c}\text { Pmax } \\
\text { CSC } \\
(\mathrm{kN})\end{array}$ & $\begin{array}{r}\text { Rasio } \\
\text { teori/eksp }\end{array}$ \\
\hline 200 & 39,37 & 196,18 & 5,0 \\
\hline 300 & 39,05 & 171,02 & 4,4 \\
\hline 600 & 37,03 & 111,14 & 3,0 \\
\hline 900 & 32,68 & 74,66 & 2,3 \\
\hline 1200 & 25,91 & 61,58 & 2,4 \\
\hline \hline
\end{tabular}

Keterangan:

- Pcr teori : beban maksimum

- Pmax CSC : beban maksimum batang komposit laminasi kayu-baja ringan 
Kenaikan kapasitas tekan berbeda-beda untuk setiap panjang tekuk $\left(\mathrm{L}_{\mathrm{k}}\right)$. Kenaikan kapasitas tekan struktur tersebut berbanding terbalik dengan panjang tekuknya, semakin besar panjang tekuknya semakin kecil kenaikan kapasitas tekannya begitu pula berlaku sebaliknya.

Deformasi lateral yang terjadi pada profil baja ringan dan pada batang komposit laminasi kayu-baja ringan dapat disimpulkan bahwa deformasi lateral yang terjadi pada bentang pendek meningkat ketika profil baja ringan tersebut dikompositkan dengan kayu. Namun pada bentang yang lebih panjang deformasi lateralnya cenderung sama. Hal ini karena pada bentang pendek profil baja ringan hanya terjadi local buckling saat beban maksimum tercapai, dengan bentang yang sama pada struktur kompositnya terjadi global buckling saat beban maksimumnya tercapai. Pada bentang panjang kedua sistem struktur tersebut mengalami ketika terbebani tekan pola kegagalanya berupa global buckling, namun bedanya pada profil baja ringan mengalami torsi karena beban tekan sedangkan pada model komposit tidak terjadi torsi.

Penambahan kayu sebagai material komposit dalam struktur ini jelas terurai di atas. Strukutur komposit ini secara signifikan menambah kapasitas tekan profil baja ringan dan mengurangi terjadinya local buckling yang terjadi pada profil baja ringan akibat beban tekan. Selain kapasitas tekannya yang bertambah, berat dari struktur tersebut juga mengalami peningkatan. Berikut perbandingan penambahan kapasitas tekan komposit dengan penambahan beratnya.

Pertambahan berat untuk setiap panjang tekuk yaitu rata-rata 4,5 kali. Pada struktur dengan panjang $1300 \mathrm{~mm}$ mengalami pertambahan tekannya 3,0 kali dari kapasitas tekan profil baja ringan, berat strukutrnya bertambah menjadi 4,3 kali dari struktur baja ringan tanpa komposit. Semakin panjang panjang tekuk akan semakin kecil efektifitas pertambahan kapasitas tekannya namun pertambahan beratnya akan tetap. Maka pada panjang tertentu model ini tidak dapat digunakan lagi untuk alternatif model struktur tekan karena pertambahan kapasitas tekannya tidak sebanding dengan pertambahan beratnya. Harus dilakukan pemodelan yang lain sehingga perbandingan pertambahan berat dengan pertambahan kapasitas tekannya lebih baik.

\section{KESIMPULAN}

Hasil dari penelitian ini dapat disimpulan sebagai berikut:

1. Laminasi kayu mahoni cenderung lebih besar kapasitas tekan kayu mahoni hingga 5 kali lipat jika dibandingkan dengan analisis teori transfomasi tampangyang mengacu pada SNI 7973-2013 Spesifikasi desain untuk konstruksi kayu.

2. Model keruntuhan batang komposit adalah tekuk pada sayap profil baja ringannya, dan pada badan secara keseluruan model kegagalannya hanya mengalami tekuk global akibat kelangsingan batangnya bukan hancur karena penampang.

3. Prediksi kapasitas tekan batang komposit tersebut tidak dapat didekati dengan menggunakan metode transformasi penampang maupun menggunakan teori Euler dengan modulus Elastisitas komposit.

\section{SARAN}

1. Diperlukan ketelitian dalam pembuatan benda uji, utamanya pada kerataan ujung-ujung benda uji agar parameter-parameter penelitian didapatkan dengan baik.

2. Diperlukan pemodelan yang lebih baik untuk mendapatkan penambahan kapasitas tekan yang lebih baik.

3. Perlu dilakukan analisis numerik untuk mengetahui pendekatan perhitungan kapasitas tekan untuk batang komposit dengan panjang tekuk yang lain atau model komposit yang lain. 


\section{DAFTAR PUSTAKA}

Gere,J.M., dan Ttimoshenko, S.P, 2000, Mekanika Bahan Jilid 1 (edisi keempat ed.). (Suryoatmono, Penerj.) Jakarta, Penerbit Erlangga.

Gere,J.M., dan Ttimoshenko, S.P. 2000. Mekanika Bahan Jilid 2 (edisi keempat ed.). (Suryoatmono, Penerj.) Jakarta, Penerbit Erlangga.

Li, X,2005, Composite Beams Of Cold Formed Steel Sections And Wood Members, Thesis. The University Of New Brunswick.

Setiyono, H, 2008. Investigasi Analitis dan Eksperimental Kekuatan Profil Baja Ringan Terhadap Interaksi Local dan Global Buckling. Laporan Penelitian, UPT Laboratorium Uji Konstruksi. Badan Pengkajian danPenerapanTeknologi.

Sinaga, R.M., 2005, Perilaku Lentur Baja Profil C Tunggal dengan
Menggunakan Perkuatan Tulangan Arah Vertikal, Final Project, Civil Engineering Department, Faculty of Engineering, Universitas Atma Jaya Yogyakarta.

Wigroho, Y.S, 2008, Kuat Lentur Profil C Tunggal dengan Perkuatan Tulangan Vertikal Dan Cor Beton Pengisi, Jurnal Teknik Sipil, Volume 8 No. 3, hal $264-277$.

Winter, dkk, 2012, Timber-steel-hybrid beams for multi-storey buildings, Auckland, World Conference on Timber Engineering.

Wahyu, D dan Nugroho, M, 2008. Tinjauan Hasibhasil Penelitian Faktor- faktor Alam yang Mempengaruhi Sifat Fisik dan Mekanik Kayu Indonesia, Jurnal llmu dan Teknologi Kayu Tropis, Masyarakat Peneliti Kayu Indonesia. Vol.5(1):85-100.

Yu, W.W, 2000, Cold Formed Steel Desaign $3^{r d}$ ed, Jhon Wiley \& Sons Inc 